\title{
日本保険学会会報 $\left(\begin{array}{l}\text { 自: 平成28年 } 4 \text { 月 } 1 \text { 日 } \\ \text { 至: }\end{array}\right.$
}

平成28年度も保険に関する研究と保険研究者相互の協力を促進し, 国内および国外の関 係学会または関係団体との連絡および協力を図ることを目的として, 諸事業を実施した。

\section{1. 平成28年度総会および年次大会}

立命館大学を開催校として, 以下のとおり開催した。

\section{<定時総会>平成28年10月29日(土), 11：10１1：45（立命館大学 衣笠キャンパス 存心館701号教室）（約80名出席）}

羽原理事 (関西大学) を議長として, 議事に入った。概要, 次のとおり。

$\bigcirc$ 第 1 号議案 平成 27 年度事業報告及び平成 27 年度決算（案）

福田理事長より, 第 1 号議案について説明があった。次いで鈴木監事から監事を代表

して監査報告があり，全員異議なくこれを了承した。

$\bigcirc$ 第 2 号議案 平成 28 年度事業計画（案）及び平成28年度予算（案）

福田理事長より, 金澤 理先生 (早稲田大学名誉教授) および石田 満先生（上智大学 名誉教授）を名誉会員として推薦したい旨，説明があり，特に異議なく了承した。

$\bigcirc$ 第 3 号議案 名誉会員の推薦

福田理事長より, 真屋尚生先生（日本大学名誉教授）を名誉会員として推薦したい旨, 説明があり，異議なく了承した。

第 4 号議案 日本保険学会会則改正

福田理事長より, 会則第 11 条第 2 項の改正, 第 12 条, 第 13 条, 第 14 条の追加, 第 16 条 の一部改正および追加, 第17条, 18条の改定, 第25条(旧24条)の改正につき, 提案があ

り，異議なく了承した。

主たる改正点は,

・理事, 評議員の任期（6 期12年まで）と定年制（満65歳まで）を会則に明記

・理事長任期（2 期 4 年まで）を会則に明記

・理事会における決議省略の方法を規定

・「委員会・部会規則（内規）」の根拠を示し条文を会則に規定

・評議員会の運営方法を会則に明記

・来年度よりの事務局移管にともない, 会則を改正

である。

○第 5 号議案 役員及び評議員の改選

羽原議長より, 現在の役員 (理事 ·監事), および評議員は, 会則第 12 条および第 17 条第 3 項により, 今年度の総会の終了をもって任期満了となることから, 会則第 11 条第 
日本保険学会会報

1, 2 項および第 17 条第 3 項に基づき, 昨年の総会で選任された役員・評議員候補者選 考委員会委員に候補者を選考願った旨の説明があった。

続いて福田理事長より, 役員, 評議員候補者50名の披露があり, 異議なく了承した。

第 6 号議案 普通会員会費改定

福田理事長より，昭和61年 (1986年)から30年間, 5,000円で据え置いてきた普通会員 会費を, 来年度から年間 6,000 円（但し, 大学院生は3,000円に值下げ）に改定すること とした, との報告があった。今後の学会の健全な発展のために, 必要な施策であるとの 説明がなされた。

$\bigcirc$ 第 7 号議案 第 6 回日本保険学会賞発表

洲崎学会賞選考委員長より, 学会賞選考委員会が第 6 回日本保険学会賞の選考を行っ たので発表するとして，以下の報告があった。

日本保険学会賞（著書の部）：

中出 哲 (早稲田大学)

『損害てん補の本質一海上保険を中心として一』

成文堂刊 (平成28年 3 月)

日本保険学会賞（論文の部）：

古村 聖 (武蔵大学)

「夫婦間交涉力と生命保険需要に関する実証研究」

(生命保険論集194号掲載)

引続き福田理事長より受賞者 2 名に対して, 賞状ならびに副賞が授与された。

\section{<大会研究報告 $>$ 平成28年10月29日(土) - 30日(日) 於：立命館大学}

参加者数：会員174名, 来賓16名, 会員外 34 名, 報道関係者 2 名, 合計 226 名

\section{プログラム}

\section{[第 1 日]}

【招待報告】告知義務制度の韓・日・中比較研究

報告者：朴 恩京 (慶星大学)

司会者兼通訳者：李 芝奸（東洋大学）

【シンポジウム】民事司法利用支援のための保険制度の役割

司 会 山下 典孝 (大阪大学)

(1) 弁護士費用保険を巡る諸問題

$$
\text { 大井暁（弁護士） }
$$

(2) 経済分析に基づく民事紛争への保険利用の問題と課題

池田 康弘 (熊本大学)

（3) 民事紛争支援と損害保険「権利保護保険」

木村 彰宏（損保ジャパン日本興亜） 
(4) 保険契約者等の権利保護と生命保険分野の対応

$$
\text { 一八瀬 淳（第一生命） }
$$

(5) 依頼者保護のための制度構築に関する問題

山下 典孝 (大阪大学)

\section{[第 2 日]}

\section{【自由論題】}

第 I セッション（経済・経営・商学系）

座 長：岡田 太志 (関西学院大学)

(1) 発達障害がある学生の保障に関する一考察

一実務の現場からみる保険の限界と可能性一

藤本昌（全国大学生協共済生活協同組合連合会）

(2) 戦後の相互会社化と相互会社経営の形骸化

黒木 達雄 (名古屋商科大学)

(3) 生命保険販売チャネルの多様化とチャネル別新契約特性

一募集規制の意義と課題一

$$
\text { 小山 浩一 (Break on Through) }
$$

第 II セッション（法律系）

座 長: 大塚 英明 (早稲田大学)

(1) 重複保険における保険給付の調整に関する法的規律の検討

$$
\text { 山下 徹哉 (京都大学) }
$$

(2) フランスにおける保険契約の法的構造一日仏比較法研究の基盤一

松田 真治 (帝京大学)

(3) 保険法立法時の想定と異なる実務の現状と今後の課題

一片面的強行規定に関する問題を中心に一

$$
\text { 嶋寺 基（弁護士） }
$$

【共通論題】保険法の国際比較

司 会 山野 嘉朗 (愛知学院大学)

(1) アメリカ法における保険証券解釈ルールの動向

一責任保険法リステイトメント制定企画を契機としてー

梅津 昭彦 (新潟大学)

(2) イギリスの保険契約法からの示唆

中出哲 (早稲田大学)

(3) ドイツ保険契約法上の告知義務違反とプロ・ラタ主義

潘阿憲 (専修大学)

(4) フランス・ベルギー保険契約法一憲法規範・条約規範の影響一

山野 嘉朗 (愛知学院大学) 
（5) マイナスのモラルハザード一契約法で想定していなかった保険商品の登場一 米山 高生 (一橋大学)

\section{2. 部会活動}

\section{【関東部会】}

[第 1 回報告会］（通算219回）平成28年 6 月17日(金) 会場：早稲田大学 出席者53名

(1) 団体保険の被保険者に対する募集規制の明確化と実務上の留意点

古田 一志（損害保険ジャパン日本興亜）

(2) 保険募集人の独立性一法的認識と業法改正一

大塚 英明 (早稲田大学)

(3) アンブレラ型の農業セーフティネットとしての収入保険制度について

吉井 邦恒（農林水産省農林水産政策研究所）

［第 2 回報告会］（通算220回）平成28年 9 月16日(金) 会場：損保会館，出席者73名

(1) 権利保護保険における弁護士選任に関する法的考察

應本 昌樹（弁護士）

(2) 日本と英国の地域共済に関する比較考察

宮正 一洋（神奈川県民共済）

(3) 著しい重複契約による重大事由解除

坂本 貴生（コープ共済連）

［第 3 回報告会］（通算221回）平成28年12月16日(金) 会場：損保会館, 出席者51名

(1) 自動運転車に係わる法的課題

大坪＼cjkstart護（日本損害保険協会）

(2) 共同海損に係わる York-Antwerp Rules の2016年改定とその影響

森明 (元東京マリンクレームサービス)

(3) 企業年金における年金・一時金の選択について

〜逆選択および終身年金パズルの視点から〜

谷内 陽一 (みずほ銀行)

［第 4 回報告会］（通算222回）平成29年3月17日(金) 会場：損保会館，出席者29名

(1) 一部誤記のある保険約款の適用と解釈問題

一韓国における災害死亡保険金と自殺に関する事例を中心として一

李芝妍 (東洋大学)

(2) 明治期の生命保険会社の新聞広告一保険銀行時報を中心にして一

姜 英英 (一橋大学)

(3) 地震保険改革一熊本地震とニュージーランド地震を契機として一

黒木 松男 (創価大学) 


\section{【関西部会】}

［第 1 回報告会］（通算191回）平成28年 6 月 13 日(土)

会場：関西学院大学大阪梅田キャンパス 出席者 22 名

(1) 保険の仕組みと保険契約法一保険法改正内容を保険の仕組みから検証する一

吉澤 卓哉 (京都産業大学)

(2) 生命保険金受取人の法的地位

桜沢 隆哉 (京都女子大学)

［第 2 回報告会］（通算192回）平成28年11月12日(土)

会場：関西学院大学大阪梅田キャンパス 出席者33名

(1) ベトナムにおける協同組合とマイクロインシュアランスを活用した保険市場開拓 の可能性

久保 英也 (滋賀大学)

(2) 傷害保険における原因事故の捉え方について

吉澤 卓哉 (京都産業大学)

［第 3 回報告会］（通算193回） 平成29年 2 月 18 日(土)

会場：大阪梅田ティーオージー 出席者：40名

(1) 特別講演 : 保険実務が抱える諸問題に関する研究依頼・共同研究等に適した研究 者の探索方法

$$
\begin{aligned}
& \text { 吉澤 卓哉 (京都産業大学) } \\
& \text { 山㟝 尚志 (神戸大学) }
\end{aligned}
$$

(2) 国民年金の納付率を押し下げる諸要因についての計量的分析

盛林 亮介（宮崎精鋼）

久保 英也 (滋賀大学)

(3) 第三者が関与するモラル・リスク事案への対抗策〜設定事例に基づいて〜 板東 大介（弁護士）

(4) 保険金の管理における信託の活用可能性

$$
\text { 星野 豊(筑波大学) }
$$

\section{【九州部会】}

［第 1 回報告会］（通算第44回） 平成28年7月30日(土) 会場 : 福岡大学 出席者38名

(1) 保険販売チャネルに関する一考察

$$
\text { 根本 篤司 (九州産業大学) }
$$

(2) 証券訴訟とイベントスタディーの活用一オリンパス証券訴訟を取り上げて一

溝㴊彰 (香川大学・愛媛大学連合法務研究科) 
日本保険学会会報

[第 2 回報告会］（通算第45回）平成29年 3 月18日(土) 会場：福岡大学 出席者40名

(1) 企業からの個人情報漏洩と保険による損害填補一損害の分類と保険の法的問題を 中心に一

\section{千手 崇史 (福岡工業大学)}

(2) 直接請求権のない賠償責任保険の示談代行と弁護士法72条

吉澤 卓哉 (京都産業大学)

\section{3. 会 員}

平成 29 年 3 月 31 日現在の会員数は以下のとおり。

○名誉会員：24名

○普通会員：国内関係者 905名 内訳：大学関係者 255名, その他 650名 海外関係者 8 名

合計 913 名

賛助会員：86社

\section{4. 理事会・評議員会}

\section{第 1 回理事会 平成28年 7 月 8 日(金) (於：損保会館会議室)}

1. 審議事項

(1) 入退会者

福田理事長より個人会員の入会者 28 名，退会者34名が諮られ，承認された。

(2) 新規賛助会員

福田理事長より，日本損害保険鑑定人協会を新たに賛助会員として推薦したいと の提案があり,これを承認した。会費は 5 万円である。

(3) 大会準備状況

(1)本年度大会

竹演大会実行委員長から, 平成28年度大会（立命館大学）の準備状況につき, 大会プログラム案に基づき以下のとおり説明があった。

・大会プログラムがほぼ確定した。

・自由論題の報告者が, 1 名変更となった。

(久保田隆司氏 (日本地震再保険) $\Rightarrow$ 黒木達雄教授 (名古屋商科大学) )

(2)来年度大会

久保大会企画委員長から，来年度大会（滋賀大学）の開催日が 10 月 28 日(土)，29 日(日)の両日となること, また, 現時点での大会企画案につき説明があった。久保 理事の提案には, 理事会の承認がなければ実施できない事項がいくつか含まれて いることから，引き続き検討することとなった。 
(3)大会企画委員長

福田理事長から，慣例により平成30年度大会開催校である日本大学の岡田(太) 理事に, 平成29年度大会企画委員会委員長（10月開始，任期 1 年間）を依頼した いとの提案があり, 承認された。

(4)今後のスケジュール

事務局より，8月末までに大会案内状送付，9月末を大会申込および懇親会費 振込締切日として予定している，との説明があった。昨年同様，事前にホームペ ージで質問を受付け，当日はアンケートを配布することとする。

なお，当日は，秋の観光シーズンにあたることでもあり，ホテルの早期予約が 必要との説明があった。

・現時点では韓国保険学会からの報告者名ならびに報告テーマが未定である。

・主催校の事務ロードを軽減するために, 今年も懇親会代と弁当代を事前振込 みとする。

(4) 第 6 回日本保険学会賞

6 月29日に開催された「学会賞選考委員会」において第 6 回日本保険学会賞が選 出された。洲崎委員長から以下のとおり報告があった。

日本保険学会賞 (著書の部)：

中出 哲 (早稲田大学) 『損害てん補の本質一海上保険を中心として一』

成文堂刊

日本保険学会賞（論文の部）経済・商学系：

古村 聖 (武蔵大学)「夫婦間交渉力と生命保険需要に関する実証研究」

(生命保険論集194号掲載)

日本保険学会賞（論文の部）法律系：

該当なし。

なお, 福田理事長より, 学会賞対象論文のうち 1 本が本年度選考委員である久保 理事が指導している大学院生のものであったことから, 久保理事は, 利益相反の観 点から本年度の選考委員を辞退された。後任の選考委員は, 企画委員会の推薦にも とづき, 中林理事に依頼した，との報告があり，これを了承した。

会員に対する結果報告と表彰式は，10月総会時に行う。また，受賞者には，内々 に事前連絡する。

(5) 平成 27 年度事業報告書（案）

事務局作成の平成 27 年度事業報告書（案）が提出された。本報告書は, 学会総会 に提出するものである。

福田理事長より，時間の関係もあり，今回はこの報告書（案）は審議せずに各自 持ち帰り，意見がある場合は 7 月末までに事務局まで連絡するように依頼があり， これを了承した。 
日本保険学会会報

（6）平成27年度決算書（案）

(1)決算報告

事務局から, 平成 27 年度決算 (案) および過去 10 年間の決算推移について, 以下 のとおり説明があった。

収支決算書には, 学術交流積立金の取崩収入および繰入金が含まれており, 単年 度の収支バランスが分かりにくくなっている。

この点, 監事からも指摘があったので, 今年は過去10年間の決算推移を, 学術交 流積立金の影響を除いた形で作成した。

平成 27 年度は, 収入 1,229 万円（学術交流積立金取崩収入を除く）に対し, 1,146 万円（学術交流積立金150万円を除く）の支出であり，単年度の収支バランスは， 前年度に引き続き，82万円の黒字，前年度対比では，11万円の支出減であった。 昨年度は日本保険学会75周年の年であり，

・慶應義塾大学での記念大会

・保険学雑誌75周年記念号発刊

・日本保険学会75年略史の編纂

という 3 つの記念事業を行ったにもかかわらず, 特別予算を編成することなく, 結 果的には前年よりも少ない支出での決算とすることができた。その原因としては, 堀田大会実行委員長が, 低廉な費用で記念大会を運営いただけたこと, また保険学 雑誌記念号の発刊で追加費用を要したものの, 前年に比べて, 学術交流費が百万円 ほど削減できたことで，雑誌発行費用の増をかなりカバー出来たことが挙げられる。 とはいえ, 過去10年間でみると, 単年度決算が赤字となった年が全体の半分の 5 年あり, 今後, 学会として活性化のための取り組みを進めるためには, 普通会費の 改定は必要と考える。

(2)監査報告

鈴木監事より，監事を代表して監査結果の報告があった。

(3)部会報告

関東部会, 関西部会, 九州部会の平成 27 年度収支決算状況につき, 中林関東部会 長，岡田関西部会長および事務局から報告があった。

なお，鈴木監事から，以下の意見があった。

・学術交流費の扱いについては, 現行の方式は, 以前から極めて分かりにくいと 思っていた。経常費用に当たる部分と多年度にわたって積み立てる費用とは明 確に区分すべきであり，経常費用が，その年の収入金額以内に収まっているか の確認を毎年行う必要があるが, 現在の学会の決算方式では, この点が極めて わかりにくい。今回, 事務局が作成した推移表ではこの点が分かりやすくなっ ており，評価できる。 
・学術交流積立金については, 長年の経緯があるようであるが, 来年度予算案の 策定にあたっては，積立金の性格・目的，積立て・取崩し基準につき，改めて 検討すべきである。

・今後の海外交流につき，どの国に重点をおいて行うかについては，十分な論議 が必要である。現状は, 韓国と中国中心になっているが, 他の国との交流も図 る必要があるのではないかなど, 国際交流委員会の審議に期待したい。

・学会がおかれている厳しい状況については, わざわざ手間と費用をかけて調査, アンケートなどを実施せずとも，学会役員の先生方に個別にお聴きすればわか る話である。それよりも，すでに何度か理事会でも論議されているように，若 手学者・大学院生に対しサポートする対策を, 予算面も含めて早急かつ具体的 に検討し，学会活性化を進めてはどうか。

この他，特に意見なく，平成27年度収支決算書（案）を承認した。

（7）平成28年度予算（案）修正について

事務局より，「全労済協会」「損害保険鑑定人協会」が賛助会員として承認された こと, また, 日本経済学会連合から海外出張の補助金を獲得したことにより，本年 度予算案を修正したいと提案があり，これを了承した。

(8) 会則改正

福田理事長より, 役員・評議員の定年制, 任期規定や理事会の実施回数および学 会事務局の変更規定などを盛り込んだ会則改正案が提案された。

なお，本提案については，理事会開催前に開催された企画委員会で修正提案があ り，また本日の理事会においても，理事会に係る規定に「決議の省略」についての 規定も織り込むべきとの新提案があったことから, 再度, 理事各位の意見を書面に て伺い，総会にかける会則改正案を決定することとした。

(9) 平成28年度総会・評議員会

(1)総会議長の件

福田理事長より, 出席会員の中から選出する総会議長については, 従来, 慣例 として総会出席者予定理事のうち年長の方に依頼しており, 今年度も, 羽原理事 にお願いしたいとの提案があり, 了承された。

(2)監査報告

福田理事長より，総会時における平成27年度決算報告に係る監査報告について は，鈴木監事に依頼したいとの提案があり，了承された。

(3)総会・評議員会議題

大会当日の総会ならびに評議員会の議題につき，事務局長から提案があり，了 承された。

なお, 平成29年度からの普通会員会費改定については, 後日, 理事各位に送付 する「会費改定のお知らせ(案)」をご検討いただき，これを事前に学会ホームペ 
ージに揭載して, 会員に告知する。評議員各位には, 昨年の評議員会では本議題 につき賛否両論があったことを踏まえ，3 月理事会で会費改定を決定したことを 事前に連絡することとしたい，との説明があった。

(10) 委員会・部会規則改正

福田理事長より，3 月理事会で今後の委員会・部会の役員決定方法（関西部会， 九州部会を除き, 原則として, 企画委員会が委員を選任し, 理事会の承認を得て決 定するというもの）につき，承認いただいたので，委員会・部会規則改正案を事務 局にて作成した，との説明があった。

本日は時間もないことから, 持ち帰りいただき, 意見があれば今月末までに, 事 務局宛連絡願う, との提案があり, 了承された。

本件については，11月理事会で論議する。

(11) その他

福田理事長より，名誉会員選定の新基準にもとづき，理事 8 年間の経験がなくて も, 日本の保険学会に顕著な功績のあった学者については, 名誉会員として推薦で きることになった。ついては，名誉会員候補としてふさわしい方がおられれば，7 月末までにご推䳸願いたい。推薦があった場合, 持ち回り理事会で承認が得られれ ば, 御本人の内諾を得たうえで, 総会の決議事項としたいとの提案があり, 了承さ れた。

$\left(\begin{array}{cl}7 \text { 月末までに, 下記 } 2 \text { 名の先生の推薦があり, 持ち回り理事会で承認された。 } \\ \text { ・金沢 } & \text { 理先生 (早稲田大学名誉教授) } \\ \text { ・石田 } & \text { 満先生 (上智大学名誉教授 })\end{array}\right)$

2. 報告事項

(1) 編集委員会

中浜委員長より, 大会, 部会報告の「保険学雑誌」掲載状況ならびに保険学雑誌 633号を 6 月末に発行したとの報告があった。

(2) 関東部会, 関西部会, 九州部会報告

中林部会長, 岡田(太志) 部会長および事務局より, 各部会の活動状況につき報告 があった。

(3) その他

(1)文部科学省科学研究費にかかわるパブリックコメント提出

福田理事長より，下記の経緯説明があった。

現在，文部科学省は，「科研費審査システム改革2018」というプロジェクトを 進めている。この改革の目的は 最近の科研費応募件数の増加や応募動向の変化 に伴い, 現行の「系・分野・分科・細目表」に基づく審査区分の細分化が科研費 審査のネックとなっているという認識から，より簡素な「審査区分表」を作成し， 
これを2018年度から適用しようというものである。文部科学省が提案している 審査区分表（案）の「キーワード」と現行の「系・分野・分科・細目表」の 「キーワード (記号)」を比較したところ, 法学, 経済学, 経営学の 3 分野ですべ て「保険」という文字が消されている，というゆゆしき事態になっている。

文部科学省文書では，「(キーワードは) それぞれの区分の内容を網羅している ものではなく, 応募者の選択の参考のためのもの」, と書いているが, これら 3 分野で「保険」の文字が消されてしまうと, 今後, 保険法, 保険学, 保険（商 学）関係の研究で科研費を取ることは極めて不利もしくは困難になると思われる。 一例として, これまで「商学」の中で,「保険」は比較的科研費が取りやすい分 野であったが, 細目「保険」がなくなれば, 一番競争が激しい「マーケティン グ」と同じカテゴリーになるうえ，保険プロパーの審査員に審査してもらう可能 性が無くなり，科研費獲得が一気に難しくなることが予想される。

保険専攻の院生の減少が大きな問題になっているなかで, 保険が科研費の細目 から消えれば, この問題はさらに深刻化することが予想される。また, 各大学に おいて授業のナンバリングを進める際には, 科研費の細目表をべースに論議され ることが多いと思われるが, 細目にない科目は今後大学の削減対象になる可能性 が高まる。

そこで, 数名の先生方のご協力を得て, 5 月20日に日本保険学会を代表して パブコメを提出し，また学会 HPで公表した。また，日本アクチュアリー会や生 保協会，損保協会，損保総研もそれぞれパブコメを提出したと聞いている。

(2)損保総研理事長交代

6 月21日付をもって, 学会事務局を務める損保総研の遠藤寛理事長が退任し, 佐野清明氏が新たに理事長に就任したことが報告された。なお, 佐野理事長は10 月総会時に, 学会監事に就任予定である。

\section{評議員会 平成28年10月29日(土)（於：立命館大学 衣笠キャンパス 存心館703} 教室)

竹演大会実行委員長から歓迎の挨拶があった後，福田理事長を議長として議事に入った。 冒頭, 理事長より, 評議員会は全評議員が一同に会する年に一度の機会であるので, 今年 も時間を50分間として評議員各位からの意見を広く扯聴する場とした，との説明があった。

1. 平成28年度大会・総会の件

(1) 運営について

竹湏委員長より大会プログラムに基づき今年度大会運営について報告があった。

(2) 総会議長選出

福田理事長より, 会則第18条第 6 項に基づき出席会員の中から選出する総会議長 については, 従来から慣例として総会出席予定理事のうち最年長の方にお願いして 
日本保険学会会報

おり，今年は羽原理事（関西大学）にお願いすることとしたい旨，提案があり，異 議なく了承した。

\section{(3) 名誉会員推薦}

福田理事長より, 本年度より名誉会員の選定基準を改定して, 保険学会理事経験 者以外にも, 我が国の保険学の発展に対し, 顕著な功績があった者を推薦できるこ とにしたとの説明があった。本年度は, 金澤 理先生（早稲田大学名誉教授）およ び石田 満先生（上智大学名誉教授）を名誉会員として推薦したい旨説明があり, 異議なく了承した。

(4) 会則改正

福田理事長より，会則第11条第 2 項の改正，第 12 条，第 13 条，第 14 条の追加，第 16条の一部改正および追加，第17条，18条の改定，第25条（旧24条）の改正につき, 提案があり，異議なく了承した。

(5) 普通会員会費改訂

福田理事長より，昭和61年度より5,000円に据え置かれてきた普通会員会費の引 き上げについては，昨年の評議員会でも審議したが，その後理事会でも慎重審議の 結果，来年度より6,000円に改定することに決定した由説明があり，これを了承し た。なお，大学院生については年会費を3,000円に引き下げる。

(6) 第 6 回日本保険学会賞発表

理事長より，日本保険学会賞も今年で 6 年目を迎えた。選考委員会に第 6 回日本 保険学会賞の選考を依頼していたところ, 答申を得たので, 総会の場にて発表した いとの報告があり，異議なく了承した。

2 . 平成 29 年度大会・総会の件

福田理事長より, 平成 29 年度の大会は, 久保英也理事を大会委員長として, 滋賀大学 で10月28日(土)・29日(日)の両日に開催を予定している旨報告があった。

また，久保理事より，現時点での大会準備状況の披露があった。

3 . 平成30年度以降大会の件

福田理事長より, 平成30年度は日本大学 (危機管理学部), 平成31年度は関西大学で の開催を予定しているとの報告があった。

\section{第 2 回理事会 平成28年11月25日(金)（於：損保会館会議室）}

1. 審議事項

(1) 入退会者

福田理事長より入会者 29 名，退会者 2 名の説明があり，異議なく了承された。

(2) 平成28年度全国大会

福田理事長, 竹演大会実行委員長および事務局より，10月に立命館大学で行われ た大会の総括が, 以下のとおり行われた。 
・会員等192名, 非会員34名, 合計226名の参加を得て, 成功裡に終了した。

・シンポジウムは「民事司法利用支援のための保険制度の役割」, 共通論題は「保 険法改正の国際比較」をそれぞれテーマとして実施された。なお，質疑応答は， 参加者に事前質問を提出させるかたちで運営した（数年ぶりに実施）。

・立命館大学から50万円の補助金があり，会場使用料（清掃費を含む）を支払って も約 7 万円の収入となった。このため, 学会からの補助金 60 万円のうち, 約 34 万 円を返金できる予定である。

(3) 平成28年度総会・評議員会

福田理事長より, 総会, 評議員会において決算・予算案, 会則改正, 名誉会員選 任, 会費改定など，提案どおり，すべて承認されたと報告があった。なお，今年は 総会において重要な議題が多かったことから, 例年より総会配布資料の分量を増や して，口頭報告をできる限り少なくするように工夫したとの説明があった。

(4) 平成29年度全国大会企画案

久保大会実行委員長より以下のとおり提案があった。

(1)現在の学会を取り巻く環境は極めて厳しい。来年度大会のシンポジウムは, この 問題をとりあげることとし,「今, 学会の存続をかけた若手研究者の育成」をテ ーマとしたい。

討論者としては, 学会会員の他, 日本リスク研究学会の前会長に依頼する。ま た，これまで自由なテーマで報告いただいていた韓国保険学会の報告者について は,「若手育成」について，20分程度の話を依頼し，中国保険学会の代表者も初 めて招聘し，同様の報告を依頼する。

(2)共通論題のテーマは,「自動運転革命が引き起こす保険業界の変貌とその対応」 とする。報告者は，現在選定中である。

(3)一部のプログラムを, 同時期に同じ彦根キャンパスで実施される日本リスク研究 学会との共同セッションとする。具体的には, 会期を10月27日(金)〜29日(日)の2.5 日間とし, 同学会との共同セッションなどを実施する。なお, 両学会の大会につ いては, 相互に開放し, 自由に見学できるようにすることにより, 両学会会員間 の交流を目指す。

(4)40歳未満の研究者全員がポスターを作成し, 自分の研究報告や自己アピールを行 うポスターセッションを試行する。優秀なポスターには, ポスター優秀発表賞を 与える。

(5)初日午後に若手研究者の海外学会への参加や海外ジャーナルへの投稿スキルの向 上を企図するオープニング・セッションを実施する。

６招待講演は金融庁の FinTech 関係部署の幹部に依頼する予定である。

数々の新しい試みを盛り込んだ大会運営となるが, 特段の反対はなく, 提案ど おり承認された。 
日本保険学会会報

(5) 部会・委員会委員

福田理事長より, 本日開催された企画委員会において, 新年度の部会・委員会委 員につき, 提案が行われたとして, 配布資料 (下記)にもとづき説明があった。特に 異議なく企画委員会提案を承認した。

2016年11月25日

企画委員会

\section{部会・委員会委員変更 $($ 案 $)$}

(注) 下線は新任委員 (かっこ内は前委員)

*異動日：11月26日付, 但し, 山下委員のみ来年 1 月 7 日付とする。

1. 関東部会：中林理事(部会長), 大塚理事, 岡田(太)理事, 重原理事 潘評議員 (甘利理事), 嶋寺会員 (大井理事)

2. 関西部会: 岡田(太志)理事(部会長), 羽原理事, 安井評議員

3. 九州部会：佐野前評議員 (部会長), 肥塚評議員, 小川 (浩昭) 会員 (西南学院大学)

4. 企画委員会 : 福田理事長(委員長), 甘利理事, 岡田(太志)理事, 中林理事, 村田理 事, 武田評議員, 遠山評議員, 松澤評議員

5. 編集委員会 : 中浜理事(委員長), 石田理事, 河本理事, 澤本理事, 安井評議員 山下 (典孝)評議員 (1 月 7 日付) (潘評議員)

6. 国際交流委員会 : 羽原理事(委員長), 久保理事, 大倉評議員, 金岡評議員, 黒木評 議員

7. 大会企画委員会 : 岡田(太)理事(委員長), 石田理事, 久保理事, 北村評議員, 梅津 理事(甘利理事)， 丸山評議員(河本理事)，西羽評議員(新任)

8. ホームページ委員会: 村田理事(委員長), 大倉評議員, 平澤評議員, 柳瀬評議員

9. 役員等候補者選考委員会 : 竹澱理事(委員長), 甘利理事, 中林理事, 柳瀬評議員, 家森評議員, 西羽評議員

10. 学会賞選考委員会 (全員新任)：

大塚理事, 岡田(太志)理事, 小藤理事, 稲葉評議員, 山本評議員

11. 経営関連学会協議会評議員：福田理事長, 中林理事(梅津理事)

12. 日本経済学会連合評議員：洲崎理事, 堀田理事(小藤理事)

(6) 委員会·部会規則改定案

前回理事会で提案した改定案に対する種々の意見を取り入れた修正案につき，再 度審議した。

なお, 福田理事長より, 一理事から, 企画委員会のメンバー選出方法につき新提 
案があったとして説明があった。本提案については，賛成意見がなかったことから， 採用しないこととなった。

この他，特段の意見がなかったので，規則改定案は，基本的に承認された。（一 部字句を修正した改定案が，理事会終了後に配布された。）

(7) その他

福田理事長より, 今回の大会開催にあたり, ある業者から大会会場に出展したい, との依頼があった。理事各位に諮ったところ, 賛否両論があったため, 本年度大会 では実施しなかった，との報告があった。本件につき，再度理事各位に意見を求め たところ, 学会の中立性等の観点から, 有償, 無償にかかわらず, 業者の出展は当 面実施すべきではない，という結論となった。

なお， 大会時に，賛助会員団体による活動紹介もしくは同団体による情報提供は 従来どおり認めることが, 確認された。

2. 報告事項

(1) 委員会等報告

(1)保険学雑誌編集委員会

中浜委員長より，以下のとおり報告があった。

・保険学雑誌への論文投稿状況の報告。

・来年12月号は「保険自由化20年」と題して特集号を組むので，積極的な投稿 をお願いしたい。

(2)関東部会, 関西部会, 九州部会

中林部会長, 岡田 (太志)理事, 事務局より, それぞれの部会の実施状況ならび に実施予定の報告があった。関西部会については，11月例会に実務家の参加を呼 び掛けたところ，多くの実務家が参加したとの報告があった。

(2) 来年度事業計画作成依頼

福田理事長より, 昨年同様, 各部会, 委員会の事業計画をそれぞれの組織で作成 の上，事務局まで報告願う，との依頼があった。締切日は来年 1 月末とする。なお， 作成の参考として，本年度の事業計画が配布された。

\section{○第 3 回理事会 平成29年 3 月 10 日(金) （於：損保会館会議室）}

1. 審議事項

(1) 入退会者

福田理事長より, 個人会員の入会者 2 名, 退会者 9 名の説明があり, 異議なく了 承された。あわせて, 福田理事長より以下の補足説明ならびに依頼があった。

損保総研が事務局を担当した過去 7 年間の入退会状況を見ると, 入会者 382 名に 対して, 退会者362名であり，20名の純増である。特色として，

- 学者と弁護士が増えている（それぞれ，+26名，+30名）一方で, 実務家は減 
日本保険学会会報

少 $(-36$ 名) となっている。

・弁護士の増加は最近の現象であり, そのため, 退会者は少ない（ 7 年間で 4 名 のみ)。

・実務家は新旧交代が進んでいるようであり，若手実務家の入会勧誘が必要。

現在の会員数は約900名であり, 会員数1000名を目標に勧誘活動を進めていきた w。

(2) 大会企画委員会関連

久保大会実行委員長より，滋賀大学で実施する来年度大会につき，以下のとおり 報告および提案があった。

(1)来年度大会は, 数々の新機軸を盛り込んだ大会であり, また日本リスク研究学会 との連携運営で行われる初めての大会となるので, 例年より相当早い時期である 3 月 1 日に, 学会 HPで告知を行った。

(2)自由論題については, 経済・商学系, 法律系, それぞれ 3 名のエントリーとした。 これ以外にも2 名の報告希望者があったが，大会企画委員会で審議の結果，以下 6 名に依頼することとした。

なお，来年度は上記 2 セッションの他, 日本リスク研究学会との連携特別セッ ション「エマージング・リスクとその評価」を同時間に実施する。

報告時間は， 1 報告40分とし，うち10分を質疑応答時間に充てる。

・自由論題の報告者および論題，連携特別セッションの報告者は以下のとおり (敬称略)。

・第 I セッション（経済・経営・商学系） 座 長：丸山 高行評議員 (住友生命)

1.わが国損害保険会社の国際化の現状と課題鈴木 智弘(信州大学)

2. 国民年金の未納率改善に向けた Fintech を用いた払方改善策の提案

盛林 亮介（宮崎精鋼）

3. 人工降雪, 人工造雪, 及び天候デリバティブを利用した積雪リスクマネジ メントの提唱：新潟県のスキー場における事例研究

伊藤 晴祥 (国際大学)

・第 II セッション（法律系）

座 長 : 遠山 聡評議員 (熊本大学)

1. 第三者によるモラルリスクと実質的当事者の確定

板東 大介（弁護士）

2. 第三者のためにする生命保険契約における保険金受取人と利害関係者の権 利の調整 桜沢 隆哉 (京都女子大学)

3. 自殺免責, 精神障害中の自殺 土岐 孝宏 (中京大学) 
・連携特別セッション「エマージング・リスクとその評価」

司 会：吉澤 卓哉会員 (京都産業大学)

1. 岸本 充生 (東京大学：日本リスク研究学会理事)

2. 平井祐介（経済産業省資源エネルギー庁：日本リスク研究学会会員）

3. 重原正明（第一生命経済研究所：日本保険学会理事）(人リスク）

4. 石原 康史（東京海上日動火災：日本保険学会会員）（財産リスク） 以上について，提案どおり承認した。

(3) 2 日目の昼休みを中心にポスターセッションを行う。同セッションについては, 保険学会の若手会員は原則として全員参加とし, 大会実行委員会がポスター作製 マニュアルを用意する。

その後, ポスターセッションの運営方法については種々論議が行われたが, 結 論として，本年度は以下のとおりとして運営することとした。

・「大会優秀発表賞」を設け，閉会式前に表彰式を行い，発表および表彰を行う。

・表彰状は大会実行委員長名とする。賞品は特に出さない。

・本セッションは, 今回はトライアルとして実施し, その成果を踏まえ, 平成30 年度以降も実施するかどうかを検討する。

(4)中国保険学会会長を招聘して「招待講演」を依頼する。なお，初めての招聘とい うことでもあり，今回は日本保険学会として招聘費用を負担することを承認ねが いたい（半世紀前に，韓国保険学会との交流を始めたときと同じ考え方である

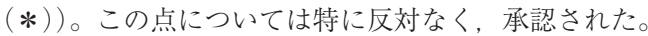

（*）木村栄一「日本保険学会50年略史」保険学雑誌・学会創立50周年記念号（1990） 102頁参照。

但し，これまで韓国保険学会に依頼していた招待講演のスタイルを変更して， 先方の会長に講演を依頼することになるので，事前に韓国保険学会にもその旨， 説明しておくべき，との意見があり，事務局からその旨，先方に連絡することと した。

(3) 平成29年度学術交流案

(1) 国際交流委員会 羽原委員長より，「学術交流積立金」見直しにつき，以下の とおり提案があった。

（i） 1966年以来，半世紀にわたって行ってきた「学術交流積立金」制度を，積立 金創設当初の趣旨に立ち戻って，「国際会議を日本国内で実施するための積立 金」に改変させることとし，名称を「国際会議等開催準備金」に変更する。

(ii) 学会の余剩資金の一部は, 必要に応じこの準備金に組み入れていく。

(iii) 平成29年度以降, 通常の学術交流費（国際交流費）については，他の支出項 目同様，当年度の収入から支出することにし，積立金からの繰り入れは行わな いこととする。 
日本保険学会会報

見直しを行う理由は以下のとおりである。

-「学術交流積立金」は, 4 年に 1 回開催されるAIDA（国際保険法学会）へ の参加費が巨額になり, 日本学術会議からの補助金等を得ても, 通常年度会計 での一括処理がむずかしいことから，学会の次期繰越金の一部を積立金とする ベく，1966年（昭和41年）に創設された制度である。昨年度末の積立金残高は 5,873,618円である。

・本学会はAIDA に1960年の同学会創設当時から深くかかわり，1962年の第 1 回大会以降, 複数の保険学会員が参加してきた。また, 当時の学会理事会で, いずれは日本での世界大会も実施したいという希望もあったことから，このよ うな積立金制度を保持してきたものと思われる。

- AIDA 積立金は, 2003年（平成15年）に「学術交流積立金」と名称を変更し, 現在では AIDA への参加費用のみならず，当年度の各種国際交流にかかわる 費用は，いったんこの項目から取り崩し，決算において費消額にほぼ見合った 丸い数字（100万円または150万円など）を戻し入れる，という処理を行ってき ている。

この決算操作については，監事から「恣意的であり，透明性に欠けるのでは ないか」との指摘を受けている。

・現在の学会の財政状況を考えると, 巨額の費用がかかるAIDA の国際大会を 近い将来，日本に招へいすることはまず不可能である。過去 2 回，東京で開催 された APRIA は，近い将来日本で開催が見込まれる他，来年度に新設される AIDAの地域会合 APIC（Asia Pacific Insurance Conference）の大会をいずれ 日本で開催する可能性もあり, これらが当学会として現実的に取り組み可能な 国際会議であろう。

当面想定される国際会議が, APRIA（経済商学系）と APIC（法律系）の

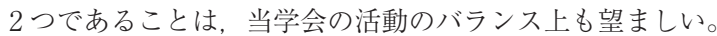

・現時点では，上記の国際会議実施のために，どの程度の金額が必要とされるか は分からないが，それなりのコストは見込む必要がある。今後も余剩資金があ れば無理のない範囲で積立を続けていくべきである。

本件については，特段の意見なく，承認された。

なお，福田理事長から，「国際会議等開催準備金」は，まずは，近い将来日本 での開催が見込まれる APRIA 大会実施費用に使用することになろうとの説明が あった。

(2)次いで, 来年度の海外学会への派遣計画につき, 以下のとおり提案があった。

・韓国保険学会年次大会（5月）：福田理事長および肥塚評議員（香川大学）を 派遣

・AIDA シンガポール理事会 (10月)：羽原理事が出席。なお，本理事会は，第 
1 回 Asia Pacific Insurance Conference 会期中に実施される。

・APRIA ポズナン大会（8月, ポーランド) : BOG（理事）である石田理事を 派遣

-中国保険学会：滋賀大学における全国大会に中国保険学会の幹部を招聘するこ ともあり，この打ち合わせも兼ねて，久保理事が 9 月に中国保険学会大会に参 加する。

また，事務局より，本件にかかわる本年度予算として148万円をみているとの説 明があった。

本件については，異議なく承認された。

(4) 平成29年度事業計画 (案)

平成29年度の事業計画（案）につき，事務局から説明があった。昨年同様，各委 員会・部会がそれぞれの計画を策定し，それをとりまとめたものである。

本件については，特段の意見なく，承認された。

（5）平成29年度予算（案）

福田理事長より, 学会事務局移管に伴い, 来年度以降, 当学会として依頼する業 務と当学会が負担する事務経費について経費関係を明確にした文書を生命保険文化 センターに提出することとしたとの報告があった。なお, 本件は, 事前に理事各位 に文書で伺いし，承認を得ているものである。

また，平成29年度予算案につき事務局から提案があった。来年度の事務局移管に ともない，特別費として30万円を見込んでいる。

特段の意見なく，本件は承認された。

(6) 学会賞選考委員会内規改定

福田理事長より，学会賞の対象論文もしくは著作で, 日本語以外で執筆されたも のを, 会員が推薦する場合は, 日本語による要約を添付すること, という規定を設 けたらどうか，との提案があり，承認された。なお，事務局によれば，外国語によ る著作が推薦された前例はないとのことである。

(7) 学会役員変更

福田理事長より，関西部会および損保総研より役員を追加または変更させたい， との下記申し出があったので，審議願いたいとの提案があった。

関西部会：菊池直人会員 (高知県立大学) を追加

庶務委員 (損保総研)：松下泰会員から三木博生会員に変更 特に意見なく，承認された。

あわせて，理事長より，現行会則では第 16 条において，委員の人数制限を規定し ているが, これは不必要な規定と思われるので来年度の総会で, 会則を改正してこ の規定は撤廃したい。次回理事会において具体的な提案を行う，との説明があった。 
日本保険学会会報

2 . 報告事項

(1) 委員会等報告

(1)保険学雑誌編集委員会

中浜委員長より, 大会・部会報告の保険学雑誌への掲載状況, 保険学雑誌 636 号の内容ならびに保険学雑誌 12 月号を「保険自由化20年特集号」として準備中で ある旨の報告があった。

(2)部会報告

中林関東部会長, 岡田 (太志) 関西部会長および学会事務局より, 関東部会, 関 西部会, 九州部会それぞれの活動状況の報告があった。

(2) その他

(1)福田理事長より, 文部科学省「科研費システム改革2018」の結果につき報告があ った。結論としては,「保険論」「保険」のキーワードが，小分類「金融およびフ アイナンス関連」では復活したものの,「民事法学関連分野」および「商学関連 分野」では復活できなかった。当学会および関連団体でパブリックコメント作成 に協力いただいた先生方，実務家各位に深謝したいとの表明があった。

なお，本件に関して，応募数が多い分野のキーワードは残ったようであるので， 今後とも保険論, 保険学分野での応募を続けていくことが大切である, との意見 があった。

(2)今回をもって，7 年間にわたった損保総研の事務局業務が終了する。損保総研佐 野理事長および松下事務局長, および 4 月より業務を担当する生命保険文化セン ターの鈴木代表理事から，それぞれ挨拶があった。

\section{5. 各種委員会における主な活動}

昨年度に引き続き, 日本保険学会の活性化に向け各種の委員会・部会等において, 下記 のとおり積極的な活動を実施した。

(1) 賛助会員・普通会費

今年度は以下の 2 団体が賛助会員として新たに加入した。

これに伴い，賛助会費は前年対比10万円増加し総額730万円を受領できた。

- (一財) 全国勤労福祉・共済振興協会

・(一社) 日本損害保険鑑定人協会

全賛助会員, ならびに賛助会費の内訳は以下のとおり。

（一社）生命保険協会 300万円

（一社）日本損害保険協会 250万円

全国共済農業協同組合連合会 60 万円

(公財) 損害保険事業総合研究所, 損害保険料率算出機構

(公財) 生命保険文化センター, (公財) かんぽ財団 
（一社）日本共済協会, 日本コープ共済生活協同組合連合会,

全国労働者共済生活共同組合連合会 各10万円

日本原子力保険プール，（一社）日本損害保険代理業協会

大学生協保険サービス, 全国大学生協共済生活共同組合連合会

損害保険労働組合連合会, (公社) 日本アクチュアリー会,

全国生命保険労働組合連合会, 中小企業災害補償共済福祉財団

（一財）全国勤労福祉・共済振興協会，（一社）日本損害保険鑑定人協会

各 5 万円

なお，普通会費については，前年度428万円に対し431万円と微増となった。

(2) 企画委員会

7 月，11月に委員会を開催し，以下の論議を行なった。

(1)普通会員会費改訂告知

(2)会則, 委員会・部会規則改正

(3)日本保険学会賞のあり方

(4)新年度部会・委員会委員

(3) 編集委員会

平成28年度は,「保険学雑誌」を下記のとおり 4 回発行した。なお，第635号は「保 険募集特集号」として刊行した。

- 第633号：平成28年 6 月

- 第634号：平成28年 9 月

- 第635号：平成28年12月

- 第636号：平成29年 3 月

(4) 大会企画委員会

大会内容をより充実させ，本学会の存在意義を発揮する中核的役割を果たすため， 平成28年度大会 (立命館大学) 開催準備を行った。なお，10月，3月に実施した委員 会では平成29年度大会（滋賀大学）の準備を行った。

(5) 国際交流委員会

本年度も APRIA(成都)および中国保険学会会合に学会の代表者を派遣した。

また, 韓国保険学会とは先方の学会に代表者を派遣, また当学会の大会には, 先方 からの招待報告を実施した。

今年度は 1 月に委員会を開催し, 以下の論議を行った。

・来年度海外学会派遣者および学術交流費予算案検討

- AIDA 対応（第 1 回 APIC 会合, 2018年世界大会）

- 学術交流費見直し

(6) ホームページ委員会

新着情報自動送信システムを活用して，タイムリーな情報発信に心がけた。 
日本保険学会会報

なお，本年度は委員会の会合を実施せず，意見交換は委員間のメール交換で行った。

(7) 学会賞選考委員会

6 月に会合をもち，第 6 回日本保険学会賞の選考を行なった

\section{6. 会計状況}

平成 27 年度決算, 平成 28 年度予算は後掲のとおり。

いずれも平成28年10月29日に開催された総会において承認された。 
平成27年度

$\frac{\text { 収 } \begin{array}{c}\text { 支 } \\ \text { 計 算 書 }\end{array}}{\left(\begin{array}{ll}\text { 自 } & \text { 平成27年 } 4 \text { 月 } 1 \text { 日 } \\ \text { 至 } & \text { 平成28年 } 3 \text { 月31日 }\end{array}\right)}$

日本保険学会

(単位：円)

\begin{tabular}{|c|c|c|c|}
\hline \multicolumn{2}{|l|}{ 支 出 } & \multicolumn{2}{|c|}{ 収 入 の 部 } \\
\hline 費 & $3,244,783$ & 賛 助 会 豆 & $7,200,000$ \\
\hline 会費 & 600,000 & 普 通 会 豆 & $4,275,550$ \\
\hline 会費 & $1,177,475$ & 購 読 会 香 & 500,000 \\
\hline 雑 誌 発 行 費 & $5,285,245$ & 刊行 物 収 & 188,000 \\
\hline 学 術 交 流 費 & 824,057 & & \\
\hline ホームページ運営費 & 331,560 & 利 & 1,016 \\
\hline 予 & 0 & & \\
\hline & & 学術交流積立金取崩収 & 824,057 \\
\hline 学術交流積立金繰入 & $1,500,000$ & 収 & 120,000 \\
\hline 小 & $12,963,120$ & 小 & $13,108,623$ \\
\hline 次期 繰 越 金 & $5,479,540$ & 前期 繰 越 今 & $5,334,037$ \\
\hline 合 & $18,442,660$ & 合 & $18,442,660$ \\
\hline
\end{tabular}

貸 借 対 照 表

平成28年 3 月31日現在

日本保険学会

(単位：円)

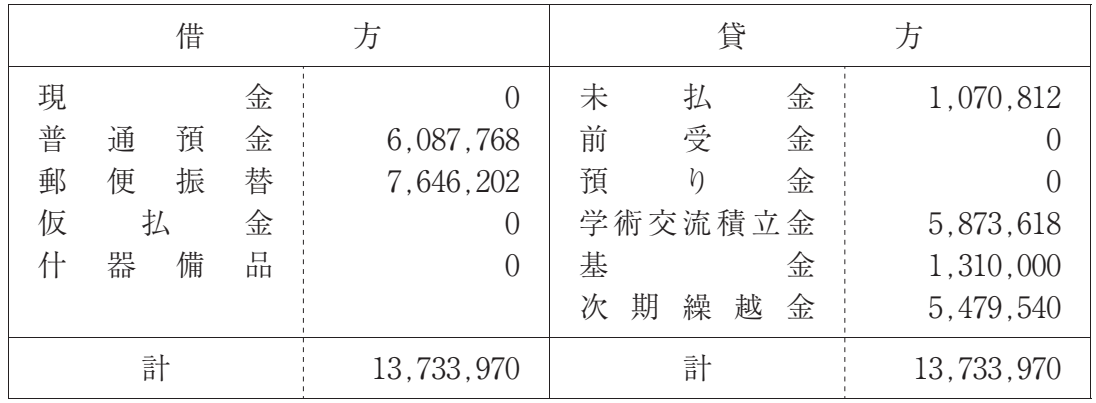

（注）基金の内訳：各務財団基金 81 万円

印南基金 50万円 
平成 28 年 度 予 算

日本保険学会

(単位：万円)

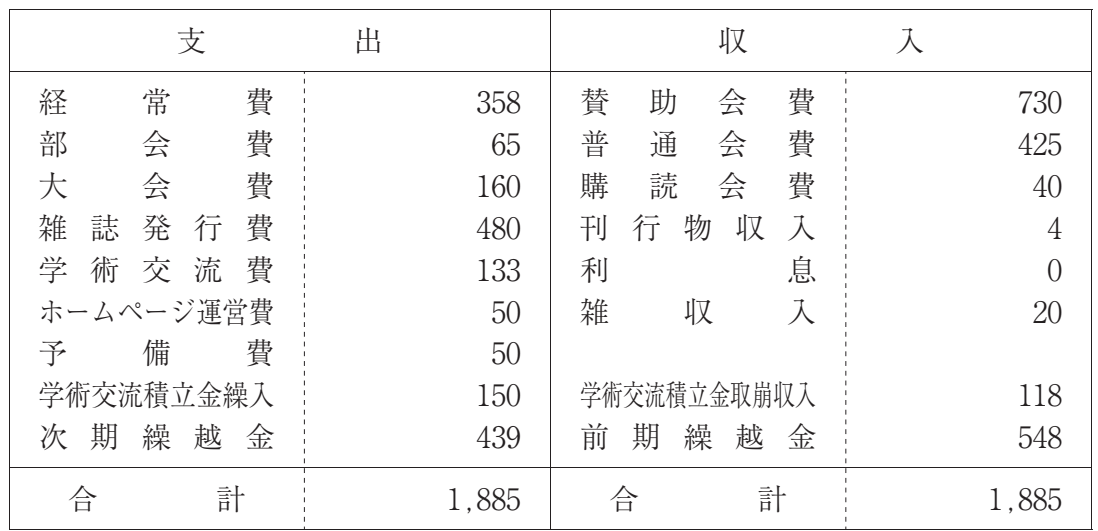

